\title{
MUSEU ESCOLAR ARNILDO HOPPEN DO COLÉGIO SINODAL DE SÃO LEOPOLDO/RS (1996-2015) \\ DOI: http://dx.doi.org/10.1590/2236-3459/58020
}

\section{ARNILDO HOPPEN EDUCATION MUSEUM AT SINODAL OF SÃO LEOPOLDO SCHOOL (1996-2015)}

\author{
Luciane Sgarbi Santos Grazziotin \\ Universidade do Vale do Rio dos Sinos, Brasil.
}

$\cos 8$

A cidade de São Leopoldo, localizada na região metropolitana de Porto Alegre, é conhecida como o berço da colonização alemã no Rio Grande do Sul. Foi nela que o Sínodo Rio-Grandense ${ }^{1}$ reuniu pequenas escolas de modo a melhorar as condições de estudo dos colonos. Neste contexto, foi lançada, em 1936, a pedra fundamental e, em 1937, ingressou a primeira turma de alunos do Colégio Sinodal.

O Museu Escolar Arnildo Hoppen localiza-se no Colégio Sinodal em São Leopoldo/ RS foi inaugurado dia 19 de maio de 1996. Arnildo Hoppen foi professor da instituição, exerceu, em 1939, o cargo de auxiliar de internato, fez parte do colegiado de gestão do Colégio e escreveu 50 anos Colégio Sinodal.

Dar visibilidade a esse espaço é um processo que se iniciou a partir das visitas ao acervo, da produção de imagens do espaço por ele ocupado, de consultas aos documentos ali depositados e, sobretudo, das narrativas de sua idealizadora, a professora Lilian Sofia Saenger.

A professora Lilian foi aluna nas décadas de 1940 e 1950, trabalhou como secretaria da escola entre 1951 e 1957 e, em 1974, retornou como professora. Pelas suas memórias foi possível entrever uma rede de elementos que tornaram possível a criação, conservação e permanência do espaço que em 1996 tornou-se oficialmente um museu escolar.

${ }^{1}$ O Sínodo Rio-Grandense é o precursor da atual Igreja Evangélica de Confissão Luterana no Brasil IECLB. Foi fundado em 20 de maio de 1886, em São Leopoldo/RS, com a presença de sete pastores e sete delegados leigos que representavam sete comunidades: São Leopoldo, São Sebastião do Caí, Santa Cruz do Sul, Igrejinha, Santa Maria, Dois Irmãos e Teutônia. 
Segundo a professora Lilian a ideia teve iniciou um pouco antes da escola completar cinquenta anos: "a gente começou a pensar a escola, ela tem uma história e ela não tá, não está reunida? É um pouco aqui, um pouco ali, e assim as coisas espalhadas" (Saenger, 2014). Recorda que havia na escola uma funcionária do áudio visual que, ao perceber esse interesse pela história da escola, "começou a juntar coisas, coisas, muitas coisas, um pouco aqui, um pouco ali, assim as coisas espalhadas" (Saenger, 2014).

Por ocasião do cinqüentenário da escola, em 1986, o então diretor recorreu à professora Líliam para coordenar os festejos. Ela comenta que o

dinheiro era pouco, mas havia uma imensa vontade de colocar algumas ideias em prática. Um ano antes da comemoração começaram a pensar em um espaço para organizar os materiais que já haviam sido recolhidos, [...] nós não tínhamos espaço, só lá em cima no administrativo que havia, o internato tinha sido dissolvido, nós tínhamos o sótão. Sótão é gostoso, gostoso, gostoso, ai que coisa mais gostosa é sótão, eu adoraria morar num sótão [...] mas quem é que vai a um museu num sótão? (Saenger, 2014).

\section{Um lugar para guardar}

O problema central da constituição do museu era ter um lugar para abrigar os materiais que estavam sendo recolhidos. Alguns espaços estavam disponíveis, mas nem um deles com potencial, de fato, para se transformar em museu escolar. Concomitante a falta de espaço, os materiais se acumulavam.

Frente à aproximação das comemorações do cinquentenário da escola era premente a escolha de um lugar para organizar os objetos e documentos recolhidos. A cada momento chegavam mais materiais: caixas de livros, jornais, atas, boletins, fotos de formatura. Segundo Saenger (2014), o processo de adequação do espaço foi complexo em função da necessidade adaptá-lo, reformá-lo e conseguir móveis para organizar a documentação. Embora recebessem apoio de um novo diretor que assumia o cargo, o dinheiro para obra continuava escasso.

A ocupação do lugar foi possível pelo apoio da direção da escola, do administrador geral e de alguns funcionários, sobretudo de um marceneiro e de uma faxineira que não mediram esforços para tornar o lugar próximo do que seria o ideal para abrigar os documentos. No início do processo foi feito um esquema para a reforma, que foi executada aos poucos. Assim, uma casa, que um dia foi internato e alojamento de professores, se transformou em museu.

Alguns ex-alunos e membros da comunidade, que possuíam vínculo com a escola, doaram móveis. Os antigos móveis, utilizados em diferentes locais da instituição, estavam sendo substituídos por outros mais modernos, esses também foram reaproveitados. A reforma era feita pelo marceneiro que adaptava guarda roupas, balcões, criados mudos e outros tantos móveis, em lugares adequados para se guardar toda a sorte de documentos.

\section{O espaço, os objetos e os documentos escritos}

Atualmente o Museu Escolar e Arquivo Arnildo Hoppen se organiza de maneira semelhante a uma residência. Alguns cômodos permanecem como se entrássemos no 
mesmo espaço ocupado no passado. Assim é com a sala; na qual permanecem os antigos móveis da recepção do internato; com os cômodos do sótão da casa, que mantém camas, guardaroupas, colchas, mosquiteiros e outros objetos. O mesmo ocorre com o andar inferior, que reproduz a cozinha e o refeitório do antigo internato, no qual estão as panelas, as louças e a antiga geladeira.

Outros cômodos foram organizados por temática: a sala onde se encontra o vestuário, com armários no qual permanecem diferentes trajes utilizados por grupos folclóricos e uniformes da escola. A sala na qual se localizam os materiais do laboratório de Ciências Naturais: onde estão preservados alguns animais taxidermizados, quadros com borboletas, vidros com répteis e microscópios de diferentes modelos, entre outros artefatos cujo propósito foi servir de recurso didático as aulas de Ciências. O recinto que contém os aparatos tecnológicos destinados a recursos áudio visuais: mimeógrafos, projetores de slides, gramofones, gravadores, mesas de som, máquinas de calcular e uma série de itens com o mesmo uso, além de instrumentos musicais.

Esses materiais compõem um conjunto de objetos que traduz uma cultura material da escola, que contribui para a construção do passado de uma instituição de ensino em uma produção de sentidos que nos remete a dimensão descrita por Escolano:

La escuela nos ha legado todo un utillaje material, un ajuar ergológico (como dirían los antropólogos), que es reflejo de su cultura empírica, de la tradición corporativa adscrita al oficio de enseñante, y en parte también de los discursos teóricos y normativos que se han proyectado sobre la educación formal. (2007, p.17)

Há uma série de outras salas nas quais se percebe a adaptação de antigos armários cujas portas foram substituídas por vidros, bem como balcões e mostradores, todos adaptados à finalidade de vitrine do passado.

Entre os muitos documentos preservados destaca-se: um conjunto de cadernos escolares, pertencentes à ex-alunos e de distintas matérias; atas; livros didáticos de diferentes disciplinas, alguns em alemão, francês e português; dicionários; atlas de geografia e botânica; relatórios de secretaria; boletins; revistas e impressos para fins didáticos; periódicos, dentre esses o jornal estudantil $O$ Ateneu; álbuns de fotografia e antigos regulamentos da escola.

Nas paredes dos cômodos e nos corredores do museu escolar outros documentos e objetos são expostos, tais como: flâmulas, diplomas, quadros de formatura, coleções de insetos, desenhos de plantas de diferentes espécies, mapas e um conjunto de recortes sobre o Sinodal referentes a matérias publicadas em jornais da região.

São muitas as possibilidades de estudos, sobretudo no campo da História da Educação. Esse espaço encontra-se aberto a pesquisadores que tenham interesse em trabalhar com a documentação ali preservada.

\section{Referências}

DÍAS, José Maria Fernandes. La etnografia en la historia de la escuela. In. BENITO, Agustín escolano; DÍAZ, José maria Hernández. La memoria y el deseo: cultura de la escuela y educación deseada. Valencia: Humanidades Pedagógicas, 2002, p. 227-230. 
ECO, Humberto. Memória vegetal e outros escritos sobre bibliofilia. Rio de Janeiro: Record, 2010.

GRAZZIOTIN, Luciane Sgarbi Santos, FRANK, Joana. Do Schüler-Beitung ao O Ateneu: marcas da cultura escolar nas páginas dos periódicos (São Leopoldo/RS, 1964-1973). Hist. Educ. (Online), v. 17, n. 40, 2013, p. 319-336.

BENITO, Agustín Escolano. La cultura material de la escuela: en el centenario de la junta para la ampliación de estudios, 1907-2007. Berlanga del Duero: Varona, 2007.

SAENGER, Lilian Sofia. Entrevista a Luciane Sgarbi Santos Grazziotin. São Leopoldo, maio, 2014.

LUCIANE SGARBI SANTOS GRAZZIOTIN é professora na graduação e no Programa de Pós-Graduação em Educação do Centro de Ciências Humanas da Universidade do Vale do Rio dos Sinos.

Endereço: Rua Santo Antonio, 717/505 - 90220-011 - Porto Alegre - RS - Brasil.

E-mail: Isgarbi@unisinos.br.

Recebido em 10 de julho de 2015.

Aceito em 3 de agosto de 2015. 